\title{
Successes and struggles with building web teams: A usability committee case study
}

\author{
Authors \\ R. Niccole Westbrook Digital Services, University of Houston Libraries, Houston, Texas, USA \\ Valerie Prilop Special Collections, University of Houston Libraries, Houston, Texas, USA \\ Elizabeth M. German Web Services, University of Houston Libraries, Houston, Texas, USA
}

\section{Introduction}

Web development in libraries has played a major role for decades. However, with the prevalence of online resources and the increasing importance of the libraries' web presence, what is the organizational and functional role of web development in libraries?, and where does authority over the web presence rest? It seems as though every library has a different model for managing their web presence, but most involve some sort of committee or work team, and the compositions of these committees and work teams varies drastically from library to library. Web management models and committee compositions are usually designed to function in their specific institution. As yet, there is not a robust literature about best practices and what works for web management, and this reflects the highly individualized nature of the solutions currently being employed

At the University of Houston Libraries several models for web management have been tried - ranging from a web management committee, to bringing in an outside consultant, to several committees responsible for various aspects of the web. It is aimed that sharing one of these experiences will contribute to a growing conversation about web management strategies, and perhaps prompt others to share their strategies and stories. To that end, this article describes the successes and struggles with one of the web teams at the University of Houston, the Assessment and Usability Committee.

\section{Literature review}

While much has appeared in library literature in recent years about usability and the development of user-centered web sites, little of this content has focused on the composition of groups responsible for the web. Most articles focus on the process, or on the project a web team has worked on, but reveal little about the formation, composition, or continuity of the team itself. Case studies abound, and while some information about web team structure can be gained in article introductions, little literature has focused on this crucial topical. Although this article focuses on the experience of the University of Houston Libraries' Assessment and Usability Committee in particular, this literature review includes resources on the formation and development of both usability focused teams and web teams in general.

The presence of some type of web team is quite common in academic libraries. Bundza et al. (2009, p. 246) report survey results that indicate that 75 percent of respondents employ some form of web team. Chen et al. (2009, p. 957) report similar numbers, with 71 percent of responding ARL libraries having some sort of web committee. A significant number of case studies appear in the literature describing - 
to one degree or another - a variety of team structures and compositions. For example, in the guide Making Library Web Sites Usable (Lehman and Nikkel, 2008), four case-study chapters reveal four different organizational strategies behind the team responsible for usability. Graves and Ruppel (2008, p. 112), in their survey of instruction librarians, found that 55 percent of responding instruction librarians had taken part in usability testing at their institutions, showing that it is not only dedicated web librarians who are interested in usability testing and user centered web design. Usability work is also frequently outsourced, or carried out in conjunction with an outside consultant. For instance, King and Jannik (2005, p. 238) describe how Georgia Tech Libraries conducted usability testing for their website redesign with the aid of a "local usability company," and how this experience allowed them to gain expertise necessary to develop an on-site usability lab for future use (King and Jannik, 2005, p. 240).

A key article in the literature of web teams, and usability teams in particular, is the Nichols et al. (2009) examination of an ongoing usability team at Oregon State University. This article helps account for the many different organizational strategies by describing the literature on team structures. This discussion brings to light two predominant approaches to usability teams: the distributed approach and the centralized approach. Significantly, Nichols et al. (2009) investigation concludes that while the approach at Oregon State has been successful for them, "one solution will not work for all institutions" and it is up to each institution to find a structure that reflects their values and works best for their organization.

Church and Fletcher (2005, p. 546) agree that investigations into the ways in which teams are formed are more important than the actual model settled upon. They highlight three common challenges with web teams: team formation, successful team support and management, and the establishment of the role of the web administrator. In particular, Church and Fletcher (2005, p. 546) stress the importance of knowledge and interest on the part of the members of the web team, stating that, "political considerations, such as [departmental representation] need to take a backseat to the realities of who knows enough to do the job". Church and Fletcher $(2005$, p. 548) highlight interest in web and usability concerns as a key factor in inclusion on a team, advising practitioners, "in a choice between skills and interest, choose interest" (p. 548). They also point out the real danger of burnout when adding web responsibilities to already full job descriptions, indicating that this will lead to poor results, "stress, frustration, and [...] burnout" (p. 548). This observation is statistically confirmed by Chen et al. (2009, p. 961), who found that dedicated staff working on usability will spend 14.21 hours per week on usability, while other staff would just spend 5.5 hours per week.

In general, there is no solid consensus as to how web teams should be constructed. In fact, the literature bears out that there is no one "right answer." The University of Houston Libraries, like many other institutions, is still seeking its own unique solution. It is hoped that the story of these initial efforts toward forming a usability team will add to the conversation on these teams and their roles, inform others of successful strategies and potential pitfalls, and contribute to the growing discourse on web team formation in libraries.

\section{Case Study}

Through the many iterations of web management at the University of Houston, one of the fundamental struggles has been balancing control of the overall web experience with control of individual units over their own web content. While there is a web services department, the extent of its purview has had has shifted over time through personnel changes, skills changes and the evolution of the overall importance 
of the libraries' web presence. In this changing environment it is difficult to have organizational structures that mirror and support the functional areas of the libraries. This creates a situation where web responsibilities have to be incorporated into other departments outside the centralized web services department. For instance, oversight of the interlibrary loan (ILL) web pages and the ILLiad system lies with the ILL unit. This allows ILL to make rapid changes to reflect policy decisions or to communicate system outages or changes. Yet ILL practitioners do not necessarily have the skill set and expertise that the Web Services department does, and may have to elicit assistance from web services in order to perform more complex tasks or make in-depth changes. In addition, the priorities of the ILL unit are necessarily focused on ILL processes and customer service - maintaining the unit's web presence frequently is put on the back burner as service issues take priority.

In order to address better the issue of balancing a consistent overall web presence with the needs of individual departments, an assessment and usability committee was formed in September 2010. The idea behind this committee was to create a group with no departmental affiliation that could perform usability testing and assessment of the web site and make recommendations to responsible units, keeping in mind the overall goals for the libraries' web presence. The remainder of this article documents the successes, failures, and ultimate restructuring of this particular approach to usability and web management, and describes the lessons learned along the way. Ultimately, it is hoped that this article will be the start of a scholarly conversation about web teams and the various structures and strategies currently being employed, whether successful or not.

The University of Houston libraries have had several committees or less formal groups working on the web presence. While this article describes the work of a particular web team, the work was done in the context of these other groups also focusing on the web. These groups included: a research guides and tutorials group which oversaw the management and creation of online resource guides and video tutorials; an OPAC advisory group and an OPAC usability group that made strategic choices about the OPAC; a user experience group with a broad view of user experience including both in-person and webbased interactions; and the web services department, which is tasked with continual web development and overall coordination of the libraries' web presence.

The case study presented describes the work of the UH Libraries' Assessment and Usability Committee, one of several groups formed in the immediate aftermath of a large-scale redesign of the libraries' website. In 2010 the UH Libraries completed a multi-year web redesign project. The project employed an organizational structure that sought to involve as many stakeholders and site users as possible. As part of this redesign process, a usability stakeholders engagement group (or SEG) was convened. This group was made up of librarians and staff members with an interest in usability testing and in library assessment in general, but did not include any members with a web design background or any formal training in usability. During the course of the redesign project, this group conducted usability tests that focused on a series of tasks performed on the old library website and, for comparison, on the newly redesigned site. The results of these tests informed the finished design of the new website. These tests were created with the website redesign process in mind, and once the newly redesigned site was completed and made public, the work of this group ceased.

Following the work of the usability SEG, the Assessment and Usability Committee was created as an appointed committee, and members selected by library administration for staggered one or two year terms. In order to provide for some continuity from earlier usability projects, and to ensure that there 
were some members of the group with a basic knowledge of usability testing and theory, two members of the now-disbanded usability SEG were brought on for one-year terms. A member of the OPAC Usability Subcommittee was given a two-year term for the same reasons, and to provide for communication and some coordination between the two continuing usability groups. The committee membership was rounded out by two librarians with an interest, although no direct experience, in usability.

The newly formed committee was charged to conduct assessment, accessibility and usability testing on the website and web-based tools and make recommendations based on the strengths and weaknesses identified, and to serve as a source of information on best web-based practices and assessment tools. The committee was not assigned any specific projects or tasks, so initial meetings focused on how work would be structured and on possible initial projects. Open meetings were scheduled with liaison librarians, student workers, and faculty members to ask for feedback about the library's new website and discovery platform. The committee also examined feedback submitted to the web services department via the library website's "website feedback" form. The website feedback link is present in the constant footer on each page of the site, and presents patrons with a short, open-ended form on which to provide their questions or comments. The Web Services department provided the group with several hundred comments gathered via the form from the time of the initial launch of the new website in May 2010 through September 2010. Based on the feedback gathered at the interviews and via the website feedback form, the Assessment and Usability Committee created a list of priority areas for usability testing. These priorities included the new discovery platform, the branch libraries and special collections pages, and the subject librarians' research guides.

As the committee began its work, it became clear that there was an issue in the composition and skills set of the group. As described above, the group was comprised mostly of librarians with either limited or no expertise in the area of usability. Because of this, the first few months after the committee was formed were spent researching usability and becoming familiar with various methods of usability testing. With the lack of expertise and broad nature of the charge too much time was spent debating where to start and attempting to pin down the group's role and responsibilities. In order to address this, the library brought in trainers for a day-long workshop on user experience and usability. This provided the entire usability team with a solid base from which to start and empowered them to begin to making usability related decisions. As the training was open to anyone at the library, it also provided those not on the committee with an idea of the committee's aims and the nature of the work of the committee. It was hoped that this would contribute to an overall culture of assessment at the library and make the ongoing work of the Assessment and Usability Committee easier.

The composition of the group was called into question by the hiring of a new web services coordinator a position that had been vacant for some time. With the addition of this position to the web services department, there was an increase in new web-related projects and an increased call for usability testing as part of the web development process. This position also included usability testing as part of its expressed duties, and how this person was to coordinate with the new Assessment and Usability Committee was initially unclear.

In order to determine how the committee and the web services department would work together, the head of web services and the new web services coordinator were invited to sit down with committee members. All parties quickly realized that members of the web services team had valuable expertise in 
the area of usability. In addition, the web services department would often be tasked with making changes recommended by the Assessment and Usability Committee. It was clear that there was a need to maintain close communication with the web services department and to facilitate this and it was mutually decided that both the head of web services and the web services coordinator would serve as ex-officio members of the committee. This allowed web services to support work of the Assessment and Usability Committee and to inform the direction of that work. The Assessment and Usability Committee gained the expertise from web services and maintained the autonomy of a free-standing committee. Everyone felt the addition was positive.

The first formal project undertaken by the committee was a one-on-one usability test of the libraries' research guides. These are instructional tools created by subject librarians using the spring share product campus guides. When the usability committee was formed, a sister committee for research guides and tutorials was also created. In the course of the work of the research guides committee, they decided to write a best practices document for the guides, and to restructure the navigation within the guides. In order to determine what aspects of the current guides were successful, and what needed to be reexamined, they decided to consult with the assessment and usability committee. Assessment and Usability began a project to design and conduct in-person usability testing on the research guides.

The initial phase of this project was script development, and the process highlighted one of the major ongoing issues that the committee faced. In their initial consultation, the Research Guides and Tutorials Committee had brought a list of questions and concerns that they had about the research guides. Correctly interpreting the intent of these questions and transforming them into a script for usability testing proved a difficult task. Committee members had different interpretations of the initial questions and different ideas about the overall direction for the test. Many hours were spent discussing individual questions, the intent behind them, and how best to include them in a usability test. In the end, developing a script that all parties found acceptable took over four months. By the time that the script had been written, beta tested, and refined for final testing, the Research Guides and Tutorials committee had been forced to begin their process without the results of the usability testing. When the usability results were presented to the Research Guides committee, they were mostly useful in confirming decisions that had already been made. This was certainly not a productive outcome of a very long and labor-intensive process.

So what went wrong? There were several factors contributing to the length of this process. In retrospect, it seems the primary issue was the nature of committee work itself, and the decision to use consensus decision making to design a usability test. As each person was working toward the goal as he or she interpreted it, every small step of the process had to be vetted, discussed, argued, compromised, and eventually agreed upon. As the Assessment and Usability Committee only met for an hour each week - which is actually a very active frequency for most committees in the UH libraries - decisions could not be made at the point of need, but were delayed until the next in-person committee meeting. Working online in a collaborative workspace was helpful, but not everyone could be counted on to contribute consistently.

The problems presented by the committee structure were further compounded by two committees working together, and the fact that both were employing consensus decision making and meeting only once a week. As questions or communications could only be aired at meetings, there was a least a week's turnaround time for questions to be answered or messages to be relayed between committees. 
As the work on the research guides test continued, the Assessment and Usability committee decided to work to address some other issues on the priority list by experimenting with smaller and faster ways to gather user feedback. The most successful of these was the "spot checks." Spot checks were simple tests of no more than one or two questions, usually paper-based or using a mobile device, which were conducted with volunteers entering and exiting the library. Volunteers were offered a small incentive, usually a piece of candy, to participate. This technique paired nicely with the formal usability test being developed for the research guides, allowing simple issues, such as language or layout, to be decided without a full-scale usability test. For instance, in order to advise the research guides group on color, font, and layout choices, students were shown printouts of the main page of a guide mocked up in several different styles and asked for their reactions. The spot checks also worked well for quick questions to help determine if users were really able to understand library jargon. For instance, students were shown printouts of a book record from the OPAC and asked to determine how to obtain the item, each mock-up using one of three terms ("request," "get it," or "get this item") in place of our current request button. Spot checks proved to be highly successful at allowing the group to get rapid feedback about small decisions. They typically only took 20 to 30 minutes and garnered 20 to 50 responses.

The spot checks proved so successful that the Assessment and Usability committee began planning and holding them on a weekly basis. Unlike the process of developing a one-on-one usability test, the committee structure proved highly successful for initiating the spot checks. While an individual working alone might have been overwhelmed with navigating the channels to be allowed to conduct such a test, with committee representation from all areas of the library the go-ahead was immediate and wholehearted. Furthermore, individual committee members were able to suggest their own spot checks and to participate to the degree they were interested in doing so. This led to much less argument over the design of the spot checks, and much more active participation in their implementation.

Despite the success of the spot checks, the nature of committee work - that is, consensus decision making, weekly meetings, varied levels of participation, etc. - continued to be a source of frustration. Every member of the committee had their primary job responsibilities to see to in addition to other committee work and scholarly pursuits. As is the case with any group of this type, some members were more able to devote time to usability committee work than others. This was a source of frustration for all members of the committee, but particularly for those in web services, for whom usability was a primary job responsibility. Having an autonomous group that moved at its own pace and set its own priorities tied to the ongoing job duties of several individuals and the overall goals of a department was a thorny issue. This remained a struggle throughout the duration of the Assessment and Usability Committee. Further attempts were made to speed up the work of the committee by breaking into project-based subgroups and letting committee members volunteer time where they were most interested and able. This met with some success, but led to a further imbalance of contribution among the committee members.

After a year, the Chair of the Assessment and Usability Committee was asked by library administration to evaluate the work of the committee and make recommendations for moving forward. At this juncture, two members of the committee who had been appointed for one-year terms were poised to roll off. This meant that two new members would have to be selected and that the process of training on usability techniques would have to be repeated, and the discussion of group norms, aims, and methods taken up again. Even though the committee had some successes, when faced with the prospect of having to stop progress on projects to re-train incoming members and re-norm the group it 
was clear that the committee structure was less than ideal for this type of work. The recommendation given to administration was ultimately that the committee be disbanded, that expertise in usability should be built in the web services department, and that responsibility for usability testing should rest with the web services coordinator. This recommendation was eventually adopted by administration. In order to support this transition, the web services coordinator was sent to a week-long training and was allowed to develop a budget for a standing usability program.

\section{Conclusion: opening a conversation}

Following the trend in the literature, the assessment and usability team spent most of its time focusing on the process of usability testing. Team members read practical works on designing and administering usability testing, but less attention was given to active team development. Although this approach seemed practical at the time, given the committee's charge and the very real need for immediate usability testing, in retrospect, it would have been advisable to spend more time early on working on group dynamics and on the process of team development as outlined in Church and Felker (2005). Table I compiles the various strategies and steps presented in Church's article for forming highly functional groups. For each area highlighted by Church and Felker (2005) ways in which the Assessment and Usability Committee succeeded, and ways in which it fell short have been listed.

\section{Table 1}

\begin{tabular}{|c|c|c|}
\hline Church's Team consideration & Our successes & Our struggles \\
\hline Roles and skills & $\begin{array}{l}\text { Diverse representations made } \\
\text { for a politically viable team }\end{array}$ & $\begin{array}{l}\text { - } \quad \text { Team did not originally } \\
\text { include key web services } \\
\text { members } \\
\text { - Variety of backgrounds/skill } \\
\text { levels led to disagreement } \\
\text { about direction }\end{array}$ \\
\hline Authority & $\begin{array}{l}\text { Had support of library } \\
\text { administration to perform } \\
\text { testing, offer incentives, and } \\
\text { report results }\end{array}$ & $\begin{array}{l}\text { Did not have authority to } \\
\text { implement changes or require } \\
\text { implementation from } \\
\text { responsible groups }\end{array}$ \\
\hline Accountability & $\begin{array}{l}\text { Library administration } \\
\text { expectations }\end{array}$ & $\begin{array}{l}\text { Usability work was not a part of } \\
\text { all committee members' job } \\
\text { responsibilities and thus was } \\
\text { often given low priority }\end{array}$ \\
\hline Resources and training & $\begin{array}{l}\text { Plenty of support given on } \\
\text { all levels. Usability } \\
\text { workshop with outside } \\
\text { trainers } \\
\text { - Money provided for testing } \\
\text { incentives } \\
\text { - Dedicated usability testing } \\
\text { room with specialized } \\
\text { software }\end{array}$ & $\begin{array}{l}\text { Level of expertise and } \\
\text { investment in usability was } \\
\text { inconsistent across committee } \\
\text { members }\end{array}$ \\
\hline Team dynamics and interactions & $\begin{array}{l}\text { - Collegial, even fun work } \\
\text { environment }\end{array}$ & $\begin{array}{l}\text { Never left the forming } \\
\text { stage; the group never } \\
\text { came to a firm agreement }\end{array}$ \\
\hline
\end{tabular}




\begin{tabular}{|c|c|c|}
\hline & $\begin{array}{l}\text { - Subgroups allowed } \\
\text { members to focus on areas } \\
\text { of particular interest to } \\
\text { them }\end{array}$ & $\begin{array}{l}\text { on its fundamental purpose } \\
\text { or aims } \\
\text { - Projects were often } \\
\text { hampered by this lack of } \\
\text { common understanding }\end{array}$ \\
\hline Communication & $\begin{array}{ll}\text { - } & \text { Intranet presence } \\
\text { - } & \text { Workshop open to } \\
\text { everyone } \\
\text { - Started with getting library } \\
\text { feedback }\end{array}$ & $\begin{array}{l}\text { - Limited meeting times with } \\
\text { meetings difficult to } \\
\text { schedule } \\
\text { - Not everyone reads the } \\
\text { intranet }\end{array}$ \\
\hline Web administrator's role & $\begin{array}{l}\text { Web services representation } \\
\text { was eventually added, and their } \\
\text { inclusion was invaluable to the } \\
\text { successes of the committee }\end{array}$ & $\begin{array}{l}\text { - Still a struggle between the } \\
\text { authority of an autonomous } \\
\text { group and the department } \\
\text { tasked with our overall web } \\
\text { presence } \\
\text { - Unclear where the lines of } \\
\text { responsibility were drawn }\end{array}$ \\
\hline
\end{tabular}

As stated above, after a year the Assessment and Usability Committee was disbanded, and the responsibility for web usability was tied to the position of web coordinator. Like the committee structure, this approach has its advantages and its drawbacks. At the University of Houston Libraries, the approach to usability is still evolving and will necessarily continue to do so as the institution grows and user needs change. So as to continue to evolve, constant exposure to new models and new ideas is necessary. It is hoped that others will contribute to this conversation, and that more descriptions and discussions of web teams and usability teams will appear in the literature. Perhaps methods that were unsuccessful in this case study were employed with great success elsewhere, or perhaps the opposite is true. Libraries will benefit from sharing the stories of how web teams are being formed and how the unique issues of each institution are being addressed.

\section{References}

Bundza, M., Vander Meer, P. and Perez-Stable, M.A. (2009), "Work of the web weavers: web development in academic libraries", Journal of Web Librarianship, Vol. 3 No. 3, pp. 239-262.

Chen, Y., Germain, C.A. and Yang, H. (2009), "An exploration into the practices of library web usability in ARL academic libraries", Journal of the American Society for Information Science and Technology, Vol. 60 No. 5, pp. 253-968.

Church, J. and Felker, K. (2005), "Web team development", Portal: Libraries and the Academy, Vol. 5 No. 4, pp. 545-554.

Graves, S. and Ruppel, M. (2008), "Usability testing and instruction librarians", Internet Reference Services Quarterly, Vol. 11 No. 4, pp. 99-116.

King, H.J. and Jannik, C.M. (2005), "Redesigning for usability: information architecture and usability testing for Georgia Tech Library's website”, OCLC Systems and Services, Vol. 21 No. 3, pp. 235-243. 
Lehman, T. and Nikkel, T. (2008), Making Library Web Sites Usable: A LITA Guide, Neal-Schuman Publishers, New York, NY.

Nichols, J., Bobal, A. and McEvoy, S. (2009), "Using a permanent usability team to advance usercentered design in libraries", Electronic Journal of Academic and Special Librarianship, Vol. 10 No. 2, available at: http://southernlibrarianship.icaap.org/ (viewed 3 August 2012). 